\title{
Phase equilibria of the Ga-Ni-As ternary system
}

D. B. Ingerly

Department of Materials Science and Engineering, University of Wisconsin-Madison, 1509 University Avenue, Madison, Wisconsin 53706

D. Swenson

Chemistry and Material Science, Lawrence Livermore National Laboratory, P.O. Box 808, Livermore, California 94551

C.-H. Jan

Intel Corporation, Portland Technology Development, 5200 N. E. Elam Young Parkway, Hillsboro, Oregon 97124

\section{Y. A. Chang}

Department of Materials Science and Engineering, University of Wisconsin-Madison, 1509 University Avenue, Madison, Wisconsin 53706

(Received 21 September 1995; accepted for publication 14 March 1996)

Phase equilibria were investigated in the $\mathrm{Ga}-\mathrm{Ni}-\mathrm{As}$ ternary system, with particular emphasis on the regions of technological importance to $\mathrm{Ni} / \mathrm{GaAs}$ electrical contacts. A $600{ }^{\circ} \mathrm{C}$ Gibbs isotherm was constructed using $\mathrm{x}$-ray-diffraction analysis and electron probe microanalysis of annealed samples. Additionally, three isopleths (NiAs-GaAs, $\mathrm{NiGa}-\mathrm{NiAs}$, and $\mathrm{NiGa}-\mathrm{GaAs}$ ) and a partial liquidus projection were established using differential thermal analysis and metallography. These data were utilized to clarify some discrepancies in the literature pertaining to the constitution of the $\mathrm{Ga}-\mathrm{Ni}$ As system, particularly questions about the existence of ternary phases. It was demonstrated that at $600{ }^{\circ} \mathrm{C}$, previously reported ternary phases were actually specific compositions of the binary phase, NiAs, which exhibits significant ternary solubility. Additional x-ray-diffraction and differential thermal analysis experiments suggested that superlattice structures based on the NiAs structure may become stable at lower temperatures. A ternary eutectic reaction was shown to occur at $810 \pm 5^{\circ} \mathrm{C}$, with eutectic point at the composition $\mathrm{Ni}_{0.48} \mathrm{Ga}_{0.30} \mathrm{As}_{0.22}$. The existence of this eutectic reaction has important ramifications for the development of Ni-based electrical contacts to GaAs because any metallization scheme with a composition within the region bounded by $\mathrm{NiGa}$, NiAs, and GaAs, as well as elemental $\mathrm{Ni}$, will experience at least partial liquid formation at temperatures greater than $810{ }^{\circ} \mathrm{C}$. () 1996 American Institute of Physics. [S0021-8979(96)07212-X]

\section{INTRODUCTION}

The fabrication of integrated circuits requires contacts with rectifying current-voltage characteristics (Schottky

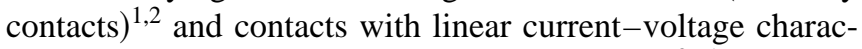
teristics and low resistivities (ohmic contacts). ${ }^{2-5}$ To be of practical use these contacts must be reproducible and reliable. Ni has been employed as a component in a wide array of both Schottky and ohmic metallization schemes in GaAs device technology. For example, NiAl, used as a rectifying contact to $n$-GaAs has been shown to enhance the Schottky barrier height upon annealing. ${ }^{1}$ In addition, $\mathrm{Ni}-\mathrm{Au}-\mathrm{Ge}$ (Refs. 2 and 3) is the standard for ohmic contacts to $n$-GaAs, while Ni-In (Refs. 5 and 6) and $\mathrm{Ni}-\mathrm{In}-\mathrm{W}$ (Ref. 7) have also been studied as ohmic contacts to $n$-GaAs. Finally, Si$\mathrm{Ni}-\mathrm{Mg}$ (Ref. 8) compounds have been researched as possible ohmic contacts to $p$-GaAs.

During the fabrication of GaAs integrated circuits, the thermal stability of the metal/GaAs contacts during hightemperature processing steps is an important consideration. Additionally, the contacts must exhibit long-term reliability at device operation temperatures. To this end, phase diagrams have been demonstrated to be important in the understanding of the reactions between metals and semiconductors, and in the selection of thermally stable metallization materials. ${ }^{9-11}$ Moreover, Lin et al. ${ }^{12,13}$ introduced the concept of using a diffusion path to rationalize phase formation sequences in metal/GaAs contacts. Phase diagrams and bulk diffusion studies provide the basic information needed for understanding phase stability and interfacial morphology in metal/GaAs contacts. ${ }^{14}$

Owing to its technological importance, the phase equilibria of the $\mathrm{Ga}-\mathrm{Ni}-\mathrm{As}$ ternary system has been studied by several groups. ${ }^{15-17}$ These studies, however, have led to a number of discrepancies about the system's actual phase equilibria. As a result of these discrepancies, many of the underlying mechanisms of the interfacial reactions in contacts between Ni-based metallizations and GaAs are still unclear. The present study was undertaken to reexamine the phase equilibria in the $\mathrm{Ga}-\mathrm{Ni}-\mathrm{As}$ system and resolve these discrepancies.

\section{EXPERIMENTAL PROCEDURE}

Isothermal phase equilibria samples were prepared with commercial semiconductor grade GaAs and elemental powders of nickel, gallium, and arsenic, all with purity greater than $99.99 \%$. Powder mixtures with total masses of $0.5 \mathrm{~g}$ were uniaxially pressed into pellets using a pressure of $30000 \mathrm{psi}$. All pellets were sealed in quartz ampoules evacu- 
ated to $10^{-4}$ Torr. The pellets were first annealed at $600^{\circ} \mathrm{C}$ for $10 \mathrm{~d}$, and then pulverized, pressed, and resealed in quartz ampoules. The pellets were then reannealed at $600{ }^{\circ} \mathrm{C}$ for 30 d. After the second annealing the samples were quenched in ice water and cut in half. One of the halves was pulverized and analyzed using a Nicolet/STOE x-ray diffractometer operating in the Bragg-Brentano mode. The other half was mounted in epoxy and metallographically cross sectioned for compositional analysis, which was done with an Applied Research Lab SEMQ electron microprobe using wavelengthdispersive spectroscopy (WDS) of x-rays.

For the isoplethal phase equilibria samples, master intermetallic alloys were prepared prior to the differential thermal analysis (DTA) experiments by weighing the desired amounts of elemental metal pieces (all with purity greater than $99.99 \%$ ) and sealing them in quartz ampoules evacuated to $10^{-4}$ Torr. These master alloys were annealed at $600{ }^{\circ} \mathrm{C}$ for 3 days to allow the elements to react, and then homogenized at $1200{ }^{\circ} \mathrm{C}$. Next, the alloys were slowly cooled to $600{ }^{\circ} \mathrm{C}$ and held there for several weeks to eliminate any possible segregation before being quenched to room temperature. DTA samples with total masses of $30-50 \mathrm{mg}$ were prepared by combining intermetallic master alloys, GaAs pieces, and elemental metal pieces to produce the desired composition. All DTA samples were sealed in quartz ampoules and annealed following the same procedure used in preparing the master alloys. A Perkin-Elmer DTA 1700 system was used to carry out the experiments. The DTA data were taken during the heating mode to prevent uncertainty in reaction temperature due to undercooling. To obtain the reaction temperatures three heating rates were used: $2^{\circ} \mathrm{C} / \mathrm{min}$; $5{ }^{\circ} \mathrm{C} / \mathrm{min}$; and $10^{\circ} \mathrm{C} / \mathrm{min}$. The data were then extrapolated to a heating rate of $0{ }^{\circ} \mathrm{C} / \mathrm{min}$. Temperature readings were calibrated using both an $\mathrm{Al}$ standard and a $\mathrm{Au}$ standard, with alumina utilized as the reference sample during data collection.

\section{RESULTS AND DISCUSSION}

The discussion evaluates the following three areas: the assessed Gibbs isotherm at $600{ }^{\circ} \mathrm{C}$; the absence of previously reported ternary phases; and the eutectic reaction enclosed in the ternary region NiAs-GaAs-NiGa, and its effect on contact formation.

\section{A. Assessed Gibbs isotherm at $600{ }^{\circ} \mathrm{C}$}

To determine the $\mathrm{Ga}-\mathrm{Ni}-\mathrm{As}$ Gibbs isothermal phase diagram at $600{ }^{\circ} \mathrm{C}, 17$ samples were prepared. These samples were limited to compositions containing less than 50 at. \% As and less than 53 at. $\% \mathrm{Ga}$, since this is the region of technological importance for the reactions in $\mathrm{Ni} / \mathrm{GaAs}$ contacts. The gross compositions of the samples and the compositions of the coexisting phases are given in Table I. Figure 1 shows the phase diagram determined using these samples, with dashed lines showing equilibria not determined by experiments but inferred from the phase rule. ${ }^{18}$ The ternary range of homogeneity of the $\gamma^{\prime}-\mathrm{Ni}_{13} \mathrm{Ga}_{9}$ phase has also been depicted using dashed lines. The reasons for this are addressed in Sec. III B.
At $600{ }^{\circ} \mathrm{C}$ five intermetallic phases exist in the $\mathrm{Ga}-\mathrm{Ni}$ binary: $\mathrm{Ni}_{3} \mathrm{Ga} ; \mathrm{Ni}_{5} \mathrm{Ga}_{3}, \gamma^{\prime}-\mathrm{Ni}_{13} \mathrm{Ga}_{9} ; \mathrm{NiGa}$; and $\mathrm{Ni}_{2} \mathrm{Ga}_{3}$. Information about their crystal structures is located in Table II. With the exception of NiGa, the ternary solubilities of the phases found in this study are consistent with what was observed by others. ${ }^{17} \mathrm{NiGa}$ was found to possess a smaller range (1 at. \%) of As solubility than was reported by Zheng et al. $^{17}$ ( $\sim 10$ at. \%). In Zheng et al.'s study of phase composition by electron probe microanalysis (EPMA), the grain size of the NiGa phase was less than $10 \mu \mathrm{m}$. This small grain size could lead to large inaccuracies in the composition measurement by allowing the electron probe to interact with grains of neighboring phases.

The only compound that forms from $\mathrm{Ga}$ and $\mathrm{As}$ is $\mathrm{GaAs}$ with the zinc-blende structure. At $600{ }^{\circ} \mathrm{C}$ EPMA shows a maximum solubility of 2 at. \% $\mathrm{Ni}$ in GaAs. This is larger than what was found by other researchers using secondary ion mass spectroscopy. ${ }^{19}$

At $600{ }^{\circ} \mathrm{C}$ the Ni-As binary consists of four compounds: $\mathrm{Ni}_{5} \mathrm{As}_{2} ; \mathrm{Ni}_{11} \mathrm{As}_{8} ; \mathrm{NiAs}$; and $\mathrm{NiAs}_{2}$. Their crystal structures are also given in Table II. $\mathrm{Ni}_{5} \mathrm{As}_{2}$ and $\mathrm{Ni}_{11} \mathrm{As}_{8}$ were found to have a small range of ternary solubility in the $\mathrm{Ga}-\mathrm{Ni}-\mathrm{As}$ ternary system, which is consistent with previous work. ${ }^{17}$ NiAs, however, exhibited a much larger solubility than was reported in prior studies. ${ }^{16,17}$

\section{B. Absence of previously reported ternary phases}

The discrepancies found in the literature about the $\mathrm{Ga}-$ $\mathrm{Ni}-\mathrm{As}$ ternary system's phase equilibria at $600^{\circ} \mathrm{C}$ center around the existence of ternary phases. Zheng et al. ${ }^{17}$ and Sands et al. ${ }^{20}$ both identified a single ternary phase with the ideal composition $\mathrm{Ni}_{3} \mathrm{GaAs}$ (denoted as the $\mathrm{T}$ phase by Zheng et al.); Guerin and Guivarc' ${ }^{16}{ }^{16}$ reported five ternary phases. In contrast to these earlier studies, the present investigation shows there is at most one ternary phase, located near the $\gamma^{\prime}-\mathrm{Ni}_{13} \mathrm{Ga}_{9}$ binary, at $600{ }^{\circ} \mathrm{C}$. All the other reported ternary phases were shown to be specific compositions of the $\mathrm{NiAs}$ solid solution which has extensive solubility in the ternary.

Both Zheng et al. ${ }^{17}$ and Sands et al. ${ }^{20}$ found the T phase to possess a crystal structure that is intermediate between that of NiAs $\left(B 8_{1}\right)$ and that of $\mathrm{Ni}_{2} \mathrm{In}\left(B 8_{2}\right)$, therefore, it was termed the $B 8_{1.5}$ structure by Zheng et al. It is important to note that the $\mathrm{T}$ phase is isostructural with the hightemperature phase, $\gamma-\mathrm{Ni}_{3} \mathrm{Ga}_{2}$, found in the Ga-Ni binary system, as will be discussed later. Zheng et al.'s work showed that at $600{ }^{\circ} \mathrm{C}$, the $\mathrm{T}$ phase was not a ternary extension of the $\gamma^{\prime}-\mathrm{Ni}_{13} \mathrm{Ga}_{9}$ solid solution phase because of the existence of a two-phase field along the $\gamma^{\prime}-\mathrm{Ni}_{13} \mathrm{Ga}_{9}-\mathrm{T}$-phase join. However, neither Zheng et al. nor Sands et al. proved that the $\mathrm{T}$ phase was not a ternary extension of the NiAs $\left(B 8_{1}\right)$ phase. Zheng et al. prepared no phase diagram samples with compositions lying between the reported $\mathrm{T}$ phase and NiAs. Sands et al.'s work was based upon transmission electron microscopy (TEM) analysis of reacted $\mathrm{Ni}$ / GaAs couples, and therefore did not address the question of the phase relationships between the $\mathrm{T}$ phase and NiAs.

Guerin and Guivarc' ${ }^{16}{ }^{16}$ used x-ray-diffraction (XRD) analysis to investigate the phase relationships of the $\mathrm{Ga}-$ 
TABLE I. Gross sample compositions, phases identified by metallography and x-ray diffraction, and compositions of phases as determined by EPMA.

\begin{tabular}{|c|c|c|c|c|c|c|c|}
\hline \multirow[b]{2}{*}{ Sample no. } & \multicolumn{3}{|c|}{ Sample compositions (at. \%) } & \multirow{2}{*}{$\begin{array}{c}\text { Phases by } \\
\text { x ray }\end{array}$} & \multicolumn{3}{|c|}{ Phase compositions by EPMA (at. \%) } \\
\hline & Nickel & Gallium & Arsenic & & Nickel & Gallium & Arsenic \\
\hline \multirow[t]{2}{*}{ GNA-1 } & 22.6 & 54.8 & 22.6 & GaAs & 0.7 & 50.8 & 48.5 \\
\hline & & & & $\mathrm{Ni}_{2} \mathrm{Ga}_{3}$ & 40.9 & 58.5 & 0.0 \\
\hline \multirow[t]{3}{*}{ GNA-2 } & 29.8 & 40.3 & 29.8 & GaAs & 2.6 & 49.8 & 47.6 \\
\hline & & & & $\mathrm{NiGa}$ & 49.2 & 50.2 & 0.6 \\
\hline & & & & $\mathrm{NiAs}$ & 51.6 & 18.6 & 29.8 \\
\hline \multirow[t]{2}{*}{ GNA-3 } & 42.5 & 15.0 & 42.5 & GaAs & a & a & $\mathrm{a}$ \\
\hline & & & & $\mathrm{NiAs}$ & $\mathrm{a}$ & a & $\mathrm{a}$ \\
\hline \multirow[t]{3}{*}{ GNA-4 } & 53.0 & 41.0 & 6.0 & $\mathrm{NiGa}$ & 46.2 & 53.8 & 0.6 \\
\hline & & & & NiAs & $\mathrm{b}$ & $\mathrm{b}$ & $\mathrm{b}$ \\
\hline & & & & $\mathrm{Ni}_{13} \mathrm{Ga}_{9}$ & 59.9 & 29.2 & 10.9 \\
\hline \multirow[t]{2}{*}{ GNA-5 } & 56.1 & 4.9 & 39.0 & NiAs & 51.6 & 5.1 & 43.3 \\
\hline & & & & $\mathrm{Ni}_{11} \mathrm{As}_{8}$ & 58.1 & 2.6 & 39.3 \\
\hline \multirow[t]{3}{*}{ GNA-6 } & 63.7 & 5.9 & 30.4 & $\mathrm{Ni}_{11} \mathrm{As}_{8}$ & 58.7 & 2.0 & 39.3 \\
\hline & & & & NiAs & 62.5 & 12.2 & 25.2 \\
\hline & & & & $\mathrm{Ni}_{5} \mathrm{As}_{2}$ & 70.0 & 1.1 & 28.9 \\
\hline \multirow[t]{3}{*}{ GNA-7 } & 69.0 & 15.5 & 15.5 & NiAs & 66.8 & 23.4 & 9.8 \\
\hline & & & & $\mathrm{Ni}_{5} \mathrm{As}_{2}$ & 72.1 & 4.9 & 23.0 \\
\hline & & & & $\mathrm{Ni}_{3} \mathrm{Ga}$ & 74.8 & 20.0 & 5.3 \\
\hline GNA-8 & 65.5 & 25.3 & 9.2 & NiAs & 66.0 & 25.1 & 8.9 \\
\hline \multirow[t]{3}{*}{ GNA-9 } & 79.6 & 10.2 & 10.2 & $\mathrm{Ni}_{5} \mathrm{As}_{2}$ & 73.1 & 2.0 & 24.9 \\
\hline & & & & $\mathrm{Ni}_{3} \mathrm{Ga}$ & $\mathrm{b}$ & $\mathrm{b}$ & $\mathrm{b}$ \\
\hline & & & & $\mathrm{Ni}$ & 85.4 & 13.1 & 1.5 \\
\hline \multirow[t]{2}{*}{ GNA-10 } & 63.0 & 13.0 & 24.0 & NiAs & 63.9 & 13.0 & 23.6 \\
\hline & & & & $\mathrm{Ni}_{5} \mathrm{As}_{2}$ & 66.0 & 9.1 & 25.0 \\
\hline GNA-11 & 60.0 & 20.0 & 20.0 & NiAs & 61.0 & 20.1 & 18.9 \\
\hline GNA-12 & 57.8 & 15.6 & 26.6 & NiAs & $\mathrm{a}$ & $\mathrm{a}$ & $\mathrm{a}$ \\
\hline GNA-13 & 54.9 & 9.8 & 35.3 & NiAs & $\mathrm{a}$ & $\mathrm{a}$ & $\mathrm{a}$ \\
\hline \multirow[t]{2}{*}{ GNA-14 } & 52.8 & 5.6 & 41.6 & $\mathrm{NiAs}$ & a & $\mathrm{a}$ & $\mathrm{a}$ \\
\hline & & & & $\mathrm{Ni}_{11} \mathrm{As}_{8}$ & $\mathrm{a}$ & $\mathrm{a}$ & $\mathrm{a}$ \\
\hline GNA-15 & 50.0 & 0.0 & 50.0 & NiAs & $\mathrm{a}$ & $\mathrm{a}$ & $\mathrm{a}$ \\
\hline GNA-16 & 60.0 & 23.5 & 16.5 & NiAs & 62.0 & 23.4 & 14.6 \\
\hline \multirow[t]{2}{*}{ GNA-17 } & 60.0 & 27.1 & 12.9 & NiAs & 62.2 & 23.6 & 14.2 \\
\hline & & & & $\mathrm{Ni}_{3} \mathrm{Ga}_{9}$ & 61.5 & 28.9 & 9.6 \\
\hline
\end{tabular}

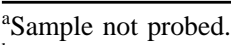

${ }^{\mathrm{b}}$ Grains too small to be probed.

$\mathrm{Ni}-\mathrm{As}$ system. By analyzing single-crystal samples they identified a series of five ternary phases, whose phase fields extended roughly along a line between the binary phases NiAs and $\gamma^{\prime}-\mathrm{Ni}_{13} \mathrm{Ga}_{9}$. Two of the phases had crystal structures of the $B 8$ type. The remaining phases possessed hexagonal superlattice structures based on the $B 8$ structure. One of these superlattice phases, denoted phase B, was found to include the composition $\mathrm{Ni}_{3} \mathrm{GaAs}$. This is in contrast to the findings of Zheng et al. and Sands et al., who did not find any indication of a $B 8$ superlattice structure at this composition. Additionally, a second ternary superlattice phase found by Guerin and Guivarc'h, denoted phase C, was found to exist over a composition range of $\mathrm{Ni}_{3} \mathrm{Ga}_{2-x} \mathrm{As}_{x}$, where $0<x<0.5$. According to Zheng et al., however, this phase is not a ternary phase but is an extension of the binary phase $\gamma^{\prime}-\mathrm{Ni}_{13} \mathrm{Ga}_{9}$. The powder XRD patterns of the phase pub- lished by each research group appear to be essentially identical; only the indexing schemes adopted by the two research groups are different.

The present investigation shows that the $\mathrm{T}$ phase is not a ternary phase in the $\mathrm{Ga}-\mathrm{Ni}-\mathrm{As}$ system at $600{ }^{\circ} \mathrm{C}$. Rather, at this temperature the previously reported $\mathrm{T}$ phase is merely a specific composition of the NiAs solution phase, which has a wide range of homogeneity in the ternary region. Furthermore, in the present study it has been found that the extent of the NiAs solution phase field comprises four of the five ternary phase fields identified by Guerin and Guivarc'h. Samples GNA-15, 14, 13, 12, and 11 (Table I) were made along the NiAs-T-phase join. All of these samples except GNA-14 were found to have single-phase XRD patterns; these single-phase patterns could be indexed based on a hexagonal unit cell. 


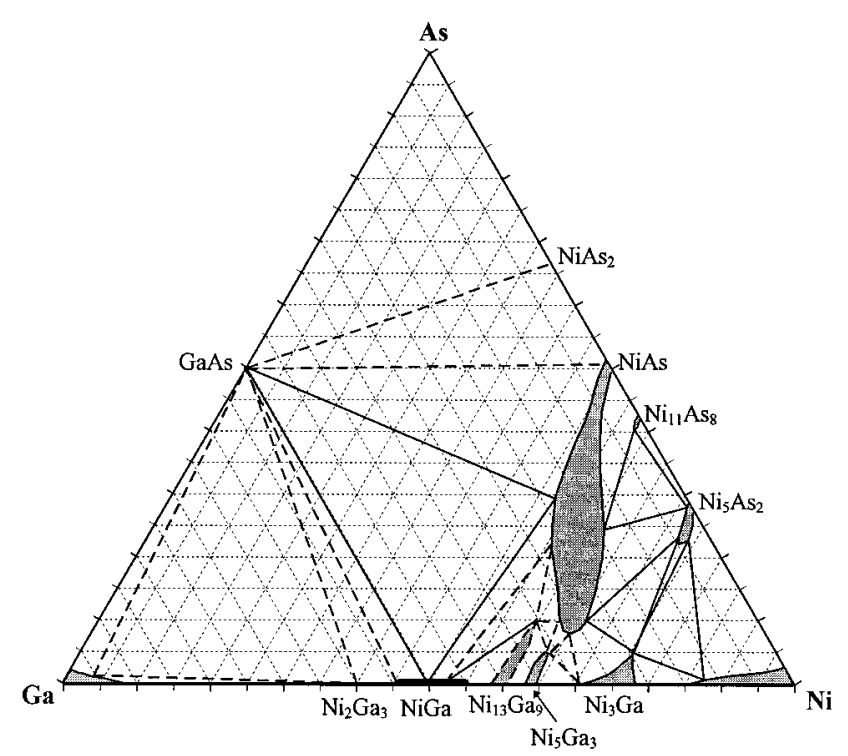

FIG. 1. The $\mathrm{Ga}-\mathrm{Ni}-\mathrm{As}$ Gibbs isotherm at $600{ }^{\circ} \mathrm{C}$.

The existence of this extensive NiAs solid solution can be rationalized based on an analysis of the hexagonal $B 8$ type crystal structures (Fig. 2). These structures have four potential interior lattice sites. In the $B 8_{1}$ crystal structure
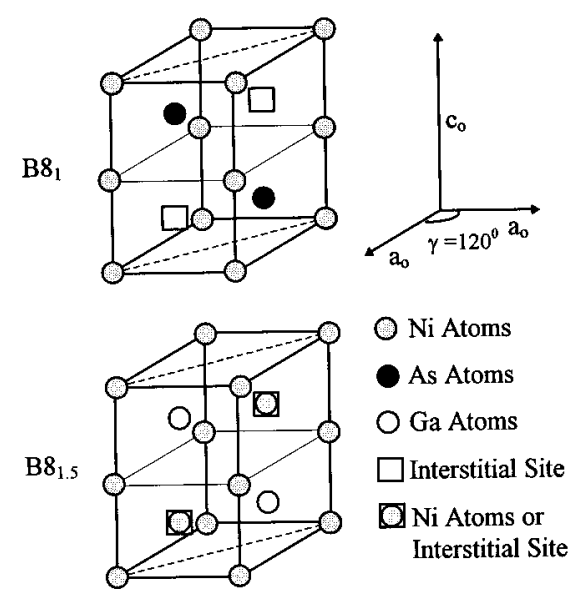

FIG. 2. Unit cells of the $B 8_{1}$ and $B 8_{1.5}$ crystal structures.

(NiAs), two of these sites are occupied by As atoms and the other two are vacant. In the $B 8_{1.5}$ crystal structure $\left(\gamma-\mathrm{Ni}_{3} \mathrm{Ga}_{2}\right)$, two of the interior sites are occupied by $\mathrm{Ga}$ atoms and the other two are half-filled by Ni atoms. It is therefore possible for a solid solution phase to extend continuously from $\mathrm{NiAs}$ to $\gamma-\mathrm{Ni}_{3} \mathrm{Ga}_{2}$ by the replacement of $\mathrm{As}$

TABLE II. Crystal structures, lattice parameters, and temperature stability of the binary compounds.

\begin{tabular}{|c|c|c|c|}
\hline Phases & Crystal structure & Lattice parameters (nm) & Temperature $\left({ }^{\circ} \mathrm{C}\right)^{\mathrm{a}}$ \\
\hline $\begin{array}{l}\mathrm{GaAs} \\
\mathrm{Ni}_{3} \mathrm{Ga} \\
\mathrm{Ni}_{5} \mathrm{Ga}_{3}\end{array}$ & $\begin{array}{l}\text { cubic, } \mathrm{ZnS}, c F 8, B 3^{\mathrm{b}} \\
\text { cubic, } \mathrm{Cu}_{3} \mathrm{Au}, C P 4, L 1_{2}{ }^{\mathrm{d}} \\
\text { orthorhombic, } \mathrm{Pt}_{5} \mathrm{Ga}_{3}, o C 16^{\mathrm{f}}\end{array}$ & $\begin{array}{l}a=0.56538^{\mathrm{c}} \\
a=.35851^{\mathrm{e}} \\
a=0.751^{\mathrm{e}} \\
b=0.678 \\
c=0.3758\end{array}$ & $\begin{array}{l}1238(c)^{\mathrm{b}} \\
1212(p)^{\mathrm{e}} \\
741(\mathrm{pd})^{\mathrm{e}}\end{array}$ \\
\hline$\gamma^{\prime}-\mathrm{Ni}_{13} \mathrm{Ga}_{9}$ & monoclinic, $\mathrm{Ni}_{13} \mathrm{Ga}_{9}, m C 44^{\mathrm{g}}$ & $\begin{array}{l}a=1.3822^{\mathrm{g}} \\
b=0.7894 \\
c=35.88^{\circ}\end{array}$ & $680(\mathrm{pd})^{\mathrm{h}, \mathrm{i}}$ \\
\hline $\begin{array}{l}\mathrm{NiGa} \\
\mathrm{Ni}_{2} \mathrm{Ga}_{3}\end{array}$ & $\begin{array}{l}\text { cubic, } \mathrm{CsCl}, c P 2, B 2^{\mathrm{h}} \\
\text { trigonal, } \mathrm{Ni}_{2} \mathrm{Al}_{3}, h P 5, D 5_{13}{ }^{\mathrm{h}}\end{array}$ & $\begin{array}{l}a=0.28955^{\mathrm{j}} \\
a=0.4054^{\mathrm{e}} \\
c=0.4882\end{array}$ & $\begin{array}{l}1220(c)^{\mathrm{h}, \mathrm{e}} \\
895(p)^{\mathrm{h}}\end{array}$ \\
\hline $\mathrm{Ni}_{5} \mathrm{As}_{2}$ & hexagonal, $\mathrm{Ni}_{5} \mathrm{As}_{2}, h P 42^{\mathrm{k}}$ & $\begin{array}{l}a=0.6815^{\mathrm{k}} \\
c=1.2506\end{array}$ & $998(c)^{1}$ \\
\hline $\mathrm{Ni}_{11} \mathrm{As}_{8}$ & tetragonal, $\mathrm{Ni}_{11} \mathrm{As}_{8}, t P 76^{1}$ & $\begin{array}{l}a=0.6870^{1} \\
c=2.1810\end{array}$ & $830(p)^{1}$ \\
\hline NiAs & hexagonal, NiAs, $h P 4, B 8_{1}{ }^{\mathrm{m}}$ & $\begin{array}{l}a=0.3619^{1} \\
c=0.5034\end{array}$ & $970(c)^{1}$ \\
\hline $\mathrm{NiAs}_{2}(\beta)$ & orthorhombic, $\mathrm{FeS}_{2}, o P 6, C 18^{\mathrm{n}}$ & $\begin{array}{l}a=0.47571^{\circ} \\
b=0.57950 \\
c=0.35442\end{array}$ & $600(\text { ed })^{\mathrm{p}}<T<825(p)^{\mathrm{q}}$ \\
\hline
\end{tabular}

${ }^{\mathrm{a} C l a s s i f i c a t i o n s: ~} c, p$, ed and pd denote congruent, peritectic melting, eutectoid and peritetic decomposition, respectively.

${ }^{\mathrm{b}}$ Reference 27.

${ }^{c}$ Reference 28.

${ }^{\mathrm{d}}$ Reference 29.

${ }^{\mathrm{e}}$ Reference 30.

${ }^{\mathrm{f}}$ Reference 31.

${ }^{\mathrm{g}}$ Reference 32

${ }^{\mathrm{h}}$ Reference 33 .
${ }^{\mathrm{i}}$ Reference 34.

${ }^{\mathrm{j}}$ Reference 35 .

${ }^{\mathrm{k}}$ Reference 36.

${ }^{\mathrm{l}}$ Reference 37.

${ }^{\mathrm{m}}$ Reference 38

${ }^{\mathrm{n}}$ Reference 39

${ }^{\circ}$ Reference 40

${ }^{\mathrm{p}}$ Reference 41 .

${ }^{\mathrm{q}}$ Reference 42 . 

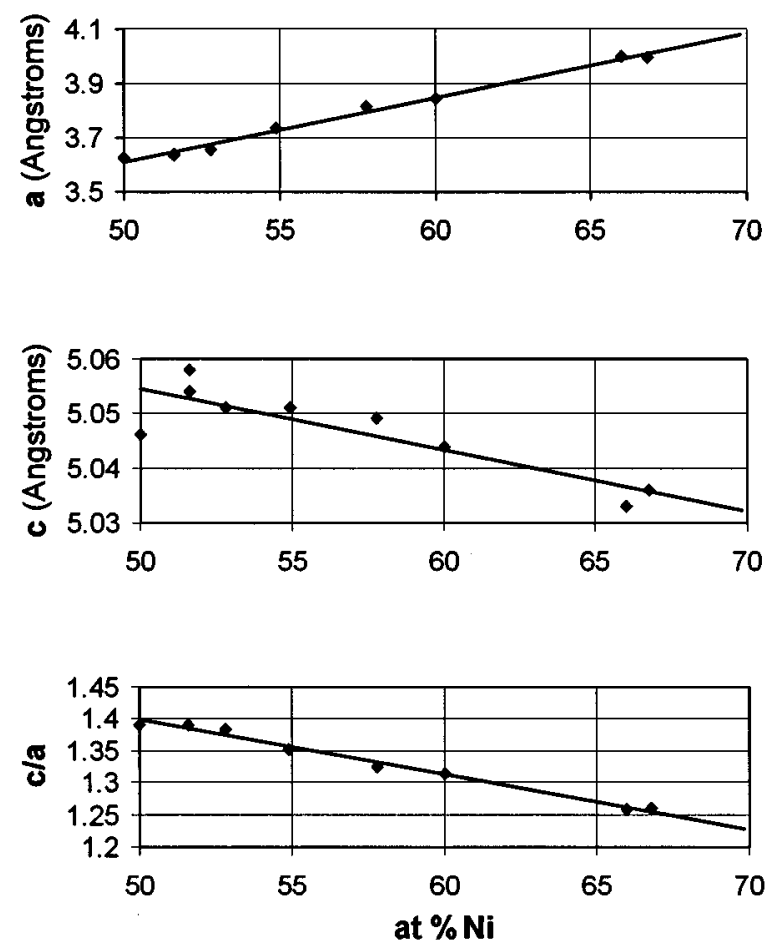

FIG. 3. Lattice parameters of the NiAs solid solution phase as function of $\mathrm{Ni}$ composition.

atoms with $\mathrm{Ga}$ atoms and the half-filling of the vacant interstitial sites with $\mathrm{Ni}$ atoms.

Based on structural arguments, it is reasonable that a continuous solid solution may form between $\mathrm{NiAs}$ and $\gamma-\mathrm{Ni}_{3} \mathrm{Ga}_{2}$. However, in the $\mathrm{Ga}-\mathrm{Ni}$ binary system the $\gamma-\mathrm{Ni}_{3} \mathrm{Ga}_{2}$ phase is only stable above $680{ }^{\circ} \mathrm{C}$, where an order-disorder transition of $\gamma^{\prime}-\mathrm{Ni}_{13} \mathrm{Ga}_{9}$ to $\gamma-\mathrm{Ni}_{3} \mathrm{Ga}_{2}$ occurs. ${ }^{21}$ Therefore, at $600{ }^{\circ} \mathrm{C}$ the ternary homogeneity range of the NiAs phase closely approaches, but cannot reach, the $\mathrm{Ga}-\mathrm{Ni}$ binary because the $B 8$-type phase is not stable in the Ga-Ni binary at this temperature.

The extensive ternary solubility of the NiAs phase is not unique to the $\mathrm{Ga}-\mathrm{Ni}-\mathrm{As}$ system. It may also be seen in the $\mathrm{Sn}-\mathrm{Ni}$-As ternary system, ${ }^{22}$ where at $800^{\circ} \mathrm{C}$ there exists a continuous solid solution between $\mathrm{NiAs}$ and $\mathrm{Ni}_{3} \mathrm{Sn}_{2}$. It is noteworthy that $\mathrm{Ni}_{3} \mathrm{Sn}_{2}$ is isostructural with $\gamma-\mathrm{Ni}_{3} \mathrm{Ga}_{2}$.

In Fig. 3 the lattice parameters of the NiAs solid solution phase are plotted as a function of Ni composition. The lattice parameters of all samples prepared for this study that exhibited the NiAs phase are included in this figure. The fact that these lattice parameter data follow Vegard's law with increasing $\mathrm{Ni}$ content is consistent with solid solution behavior. The unit-cell volume of the NiAs phase is also shown to increase continuously with increasing $\mathrm{Ni}$ composition. The increase may be explained by the fact that as one goes from the $B 8_{1}$ structure to the $B 8_{1.5}$ structure the number of atoms per unit cell increases from four to five.

The present investigation does not conclusively answer the question of whether phase $\mathrm{C}$ found by Guerin and Guivarc' $h^{16}$ is a ternary phase or a ternary extension of

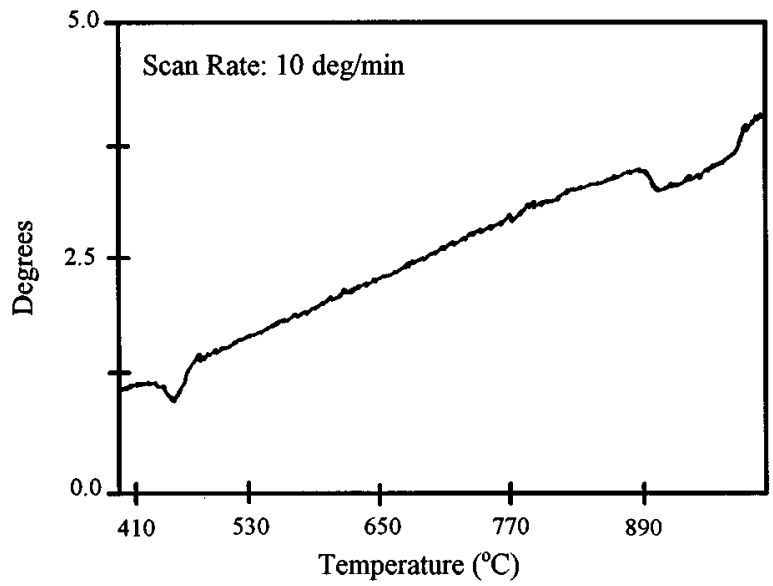

FIG. 4. Differential thermal analysis heating curve of $\mathrm{Ni}_{3} \mathrm{GaAs}$.

$\gamma^{\prime}-\mathrm{Ni}_{13} \mathrm{Ga}_{9}$, as was suggested by Zheng et al. ${ }^{17}$ According to Guerin and Guivarc'h, phase $C$ has a $2 a \times 4 c B 8$ superlattice structure. As has been discussed by Zheng et al. the structure of the $\gamma^{\prime}-\mathrm{Ni}_{13} \mathrm{Ga}_{9}$, while technically monoclinic, is very similar to that of a $2 a \times c B 8$ superlattice. Indeed, Zheng et al. pointed out that, in the past, such a superlattice structure has mistakenly been ascribed to the phase $\gamma^{\prime}-\mathrm{Ni}_{13} \mathrm{Ga}_{9}$ by more than one researcher. Even Guerin and Guivarc' $h$ have speculated that phase $\mathrm{C}$ might actually be an extension of $\gamma^{\prime}-\mathrm{Ni}_{13} \mathrm{Ga}_{9}$ into the ternary region. Nevertheless, Guerin and Guivarc'h claimed to have successfully indexed all peaks of a powder XRD pattern of phase $C$ based on a $2 a \times 4 c B 8$ superlattice structure, whereas Zheng et al. could not satisfactorily index a few weak peaks of the pattern according to the $\gamma^{\prime}-\mathrm{Ni}_{13} \mathrm{Ga}_{9}$ structure.

XRD patterns obtained in the present investigation were similar to those published by Guerin and Guivarc'h and Zheng et al. Unfortunately, Guerin and Guivarc'h did not index their published diffraction pattern or publish a list of $d$ spacings, making a rigorous comparison with their XRD patterns difficult. Overall, then, it was not possible to conclude whether one indexing scheme is superior to the other. Further XRD investigations of this phase are warranted in order to resolve this issue.

While it is clear that the only ternary phase that could exist in the $\mathrm{Ga}-\mathrm{Ni}-\mathrm{As}$ system at $600{ }^{\circ} \mathrm{C}$ is phase $\mathrm{C}$, this is not necessarily the case at lower temperatures. Swenson, ${ }^{23}$ using differential scanning calorimetry (DSC), observed a solid-state reaction between 450 and $460{ }^{\circ} \mathrm{C}$ in samples with a nominal composition of $\mathrm{Ni}_{3} \mathrm{GaAs}$. In the present investigation, the existence of this reaction was confirmed by DTA on sample GNA-11, which has the gross composition of $\mathrm{Ni}_{3} \mathrm{GaAs}$. The solid-state reaction is clearly evident in the DTA thermograph depicted in Fig. 4.

Figures 5(a) and 5(b) show a comparison of XRD patterns taken of the GNA-11 sample after being subjected to different heat treatments. Figure 5(a) is taken from a sample which was quenched, whereas Fig. 5(b) is from a sample that was slowly cooled. The quenched sample exhibits the diffraction pattern of a single phase with the $B 8_{1.5}$ crystal structure. While the diffraction pattern of the slowly cooled 



FIG. 5. X-ray-diffraction patterns of a sample with the nominal composition of $\mathrm{Ni}_{3} \mathrm{GaAs}$. (a) Quenched from $600{ }^{\circ} \mathrm{C}$, shows the existence of a single phase with the $B 8_{1.5}$-type crystal structure. (b) Slowly cooled from $600{ }^{\circ} \mathrm{C}$,

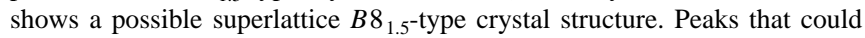
not be indexed are labeled with an $X$.

sample is similar to that of the quenched sample, it contains additional weak diffraction peaks which cannot be indexed according to the $B 8_{1.5}$ crystal structure.

The present investigators were unable to index the diffraction pattern of the slowly cooled sample, however, from its general appearance it seems to be a superlattice based on the $B 8_{1.5}$ crystal structure. The DTA and XRD data imply that at low temperatures (below $600{ }^{\circ} \mathrm{C}$ ) at least one NiAstype superlattice phase exists in the $\mathrm{Ga}-\mathrm{Ni}-\mathrm{As}$ system. Evidence of a superlattice structure has also been seen in TEM diffraction patterns of reacted $\mathrm{Ni}$ thin films on $\mathrm{GaAs}$ under certain low-temperature (below $400^{\circ} \mathrm{C}$ ) annealing conditions. ${ }^{24}$ Alternately, it is also possible that the solidstate reaction is the result of the extension of the orderdisorder transition of $\gamma^{\prime}-\mathrm{Ni}_{13} \mathrm{Ga}_{9}$ to $\gamma-\mathrm{Ni}_{3} \mathrm{Ga}_{2}$, which occurs in the binary at $680^{\circ} \mathrm{C}$, extending into the ternary.

The probable existence of one or more low-temperature $B 8$-type superlattice phases in the $\mathrm{Ga}-\mathrm{Ni}-\mathrm{As}$ system may explain in part the formation of ternary phases observed by Guerin and Guivarc'h. ${ }^{16}$ They fabricated samples which were homogenized at $1000{ }^{\circ} \mathrm{C}$ and slowly cooled to $800{ }^{\circ} \mathrm{C}$. The samples were then either quenched or slowly cooled to room temperature, with many of their samples employed in single-crystal XRD analysis being slowly cooled. Considering the observations made in the present investigation, it is

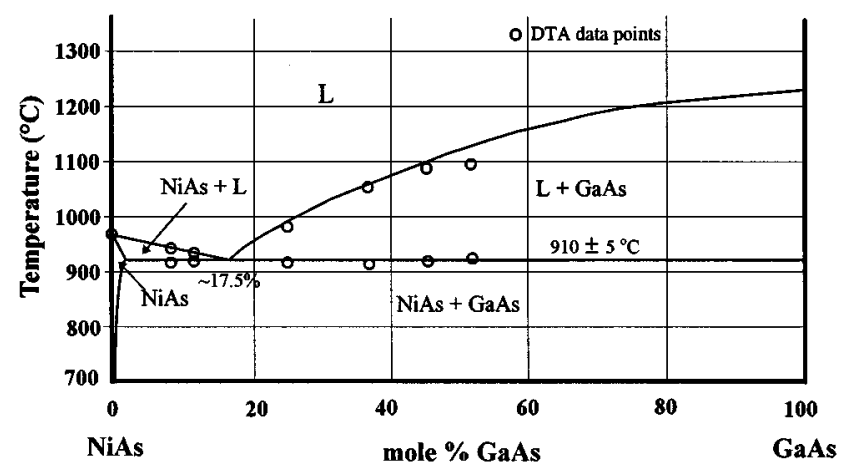

FIG. 6. The NiAs-GaAs isoplethal section.

possible that the superlattice phases found by Guerin and Guivarc'h formed from the NiAs solution phase during slow cooling are not thermodynamically stable at higher temperatures. It is also important to note that Guerin and Guivarc'h samples were annealed at $800{ }^{\circ} \mathrm{C}$, and the constitution of the $\mathrm{Ga}-\mathrm{Ni}-\mathrm{As}$ system, especially in terms of the range of homogeneity of NiAs, may be somewhat different at that temperature.

\section{Eutectic reaction enclosed in the ternary region NiAs-GaAs-NiGa and its effect on contact formation}

The temperature at which a liquid will first form can play an important role in the processing of electrical contacts. As was shown by Jan and co-workers ${ }^{6}$ using Ni/In/Ni contacts, the formation of a liquid phase can greatly change the contact's morphology and reaction kinetics. This section examines the formation of liquid phases in the ternary regions of technological importance for $\mathrm{Ni} / \mathrm{GaAs}$ contacts.

DTA was used to investigate three isoplethal sections: $\mathrm{NiAs}-\mathrm{GaAs}$, NiGa-NiAs, and $\mathrm{NiGa}-\mathrm{GaAs}$, which are shown in Figs. 6, 7, and 8, respectively. Figure 6 demonstrates that the NiAs-GaAs isopleth is a pseudobinary, exhibiting eutectic behavior with liquid formation at 910 $\pm 5{ }^{\circ} \mathrm{C}$. Figure 7 shows that a ternary eutectic reaction, $L \rightarrow \mathrm{NiAs}+\mathrm{NiGa}+\mathrm{GaAs}$, exists close to the $\mathrm{NiGa}-\mathrm{NiAs}$ join. At $42 \mathrm{~mol} \%$ NiAs complete melting occurs $820^{\circ} \mathrm{C}$.

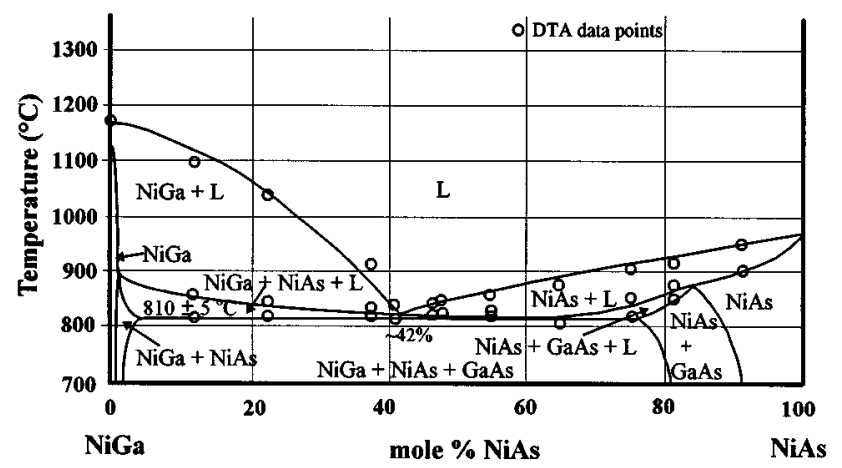

FIG. 7. The NiGa-NiAs isoplethal section. 


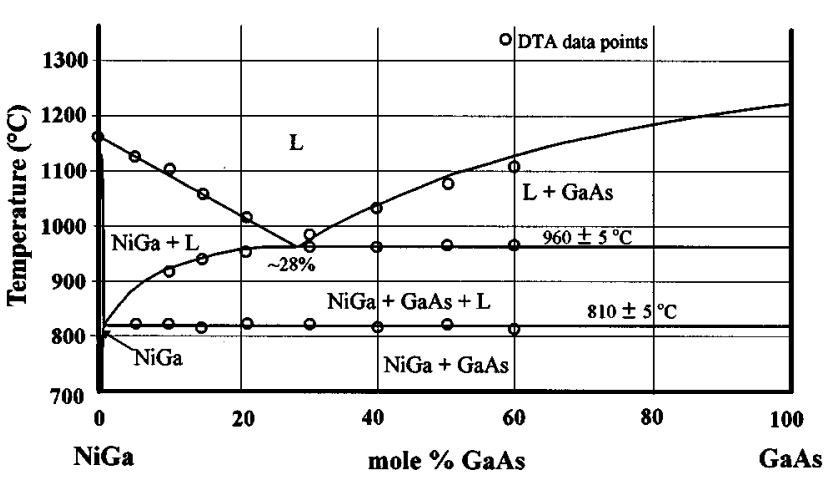

FIG. 8. The NiGa-GaAs isoplethal section.

The same ternary eutectic reaction shown in Fig. 7 causes the first liquid phase formation along the $\mathrm{NiGa}-\mathrm{GaAs}$ join (Fig. 8). Along the $\mathrm{NiGa}-\mathrm{GaAs}$ join the lowest temperature at which a single phase liquid region exists is $960 \pm 5^{\circ} \mathrm{C}$.

In conjunction with the three isoplethal sections, additional DTA analysis of samples with compositions within the $\mathrm{NiGa}-\mathrm{NiAs}-\mathrm{GaAs}$ region were used to construct a schematic liquidus projection (Fig. 9). The liquidus projection shows a ternary eutectic reaction, $L \rightarrow \mathrm{NiGa}+\mathrm{NiAs}+\mathrm{GaAs}$, occurring at the composition of $\mathrm{Ni}_{0.48} \mathrm{Ga}_{0.30} \mathrm{As}_{0.22}$. The eutectic occurs at $810 \pm 5^{\circ} \mathrm{C}$ and represents the lowest temperature at which a liquid will form within the region bounded by NiGa-NiAs-GaAs.

The existence of this eutectic reaction in the $\mathrm{Ga}-\mathrm{Ni}-\mathrm{As}$ ternary system has significant consequences for the development of Ni-based contacts to GaAs. Any metallization scheme whose composition lies within the region bounded by $\mathrm{NiGa}, \mathrm{NiAs}$, and $\mathrm{GaAs}$, including the reaction products of $\mathrm{Ni} / \mathrm{GaAs}$, will exhibit at least partial melting upon exposure to temperatures greater than $810^{\circ} \mathrm{C}$. Even phases with relatively high melting points, such as $\mathrm{NiGa}$, will react with GaAs above $810^{\circ} \mathrm{C}$ to form some liquid phase.

Based upon the results of the present investigation and those of previous researchers, a complete sequence of reactions between thin films of $\mathrm{Ni}$ and GaAs may be specified as a function of annealing temperature. It is well documented that the first phase to form in a Ni/GaAs couple has the composition $\mathrm{Ni}_{3} \mathrm{GaAs} .{ }^{20,24,25}$ As is demonstrated in the present study, this is not a ternary phase but rather is a specific composition of the solution phase $\mathrm{NiAs} . \mathrm{Ni}_{3} \mathrm{GaAs}$ will continue to grow in $\mathrm{Ni} / \mathrm{GaAs}$ diffusion couples, provided unreacted Ni remains. ${ }^{26}$ Once the $\mathrm{Ni}$ is completely consumed, $\mathrm{Ni}_{3} \mathrm{GaAs}$ will itself be consumed in a reaction with $\mathrm{GaAs}$, forming $\mathrm{NiGa}$ and As-rich NiAs ternary solution phase. $^{20,24,25}$ This represents a state of thermodynamic equilibrium, based on the present study.

However, the afore-mentioned reaction sequence is valid only for temperatures below $810^{\circ} \mathrm{C}$. According to the present investigation, at $810^{\circ} \mathrm{C}$ the presence of the eutectic reaction alters the phase equilibria of the $\mathrm{Ga}-\mathrm{Ni}-\mathrm{As}$ system such that the NiGa and As-rich NiAs solution phase will react with GaAs, forming a ternary liquid phase.

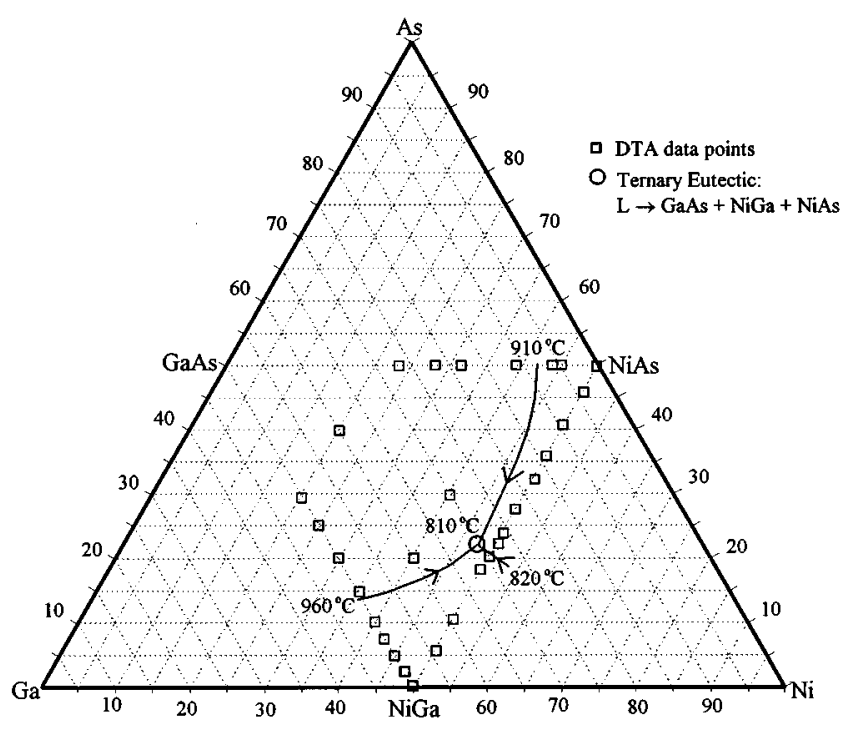

FIG. 9. A partial liquidus projection within the NiGa-NiAs-GaAs ternary region.

\section{CONCLUSION}

The technological importance of Ni-based alloys in forming electrical contacts to GaAs makes the phase equilibria of the $\mathrm{Ga}-\mathrm{Ni}-\mathrm{As}$ system important. However, in the current literature there are a number of discrepancies concerning this system, primarily pertaining to the existence of ternary phases. This study was compared to other researchers' earlier phase equilibria studies on the $\mathrm{Ga}-\mathrm{Ni}-\mathrm{As}$ system in order to resolve these discrepancies.

The phase equilibria at $600{ }^{\circ} \mathrm{C}$ in the $\mathrm{Ga}-\mathrm{Ni}-\mathrm{As}$ system were established by XRD and EPMA. The most important result of the present investigation was the demonstration that, at $600{ }^{\circ} \mathrm{C}$, NiAs possesses extensive solubility and the previously reported ternary phases were actually specific compositions of the NiAs binary phase. The wide range of homogeneity of NiAs may be rationalized based on an analysis of the crystal structures of NiAs and $\gamma-\mathrm{Ni}_{3} \mathrm{Ga}_{2}$, both having a hexagonal $B 8$-type crystal structure. However, it is still not clear whether $\gamma^{\prime}-\mathrm{Ni}_{13} \mathrm{Ga}_{9}$ possesses extensive solubility or if a ternary phase exists close to the $\mathrm{Ni}-\mathrm{Ga}$ binary. Using DSC and DTA, a solid-state reaction was found to occur at $450{ }^{\circ} \mathrm{C}$ in samples with compositions of $\mathrm{Ni}_{3} \mathrm{GaAs}$. From a comparison of XRD patterns of quenched and slowly cooled $\mathrm{Ni}_{3} \mathrm{GaAs}$, it appears that this solid-state reaction may correspond to the formation of a low-temperature superlattice phase. This possibility could account for some of the experimental observations of other researchers.

To study liquid phase formation, DTA data were used to construct isoplethal sections along the NiGa-NiAs, NiAs$\mathrm{GaAs}$, and NiGa-GaAs joins. In addition to the isoplethal sections, a partial liquidus projection within the $\mathrm{NiGa}-$ $\mathrm{NiAs}-\mathrm{GaAs}$ region was given. A ternary eutectic reaction $L \rightarrow \mathrm{NiGa}+\mathrm{NiAs}+\mathrm{GaAs}$ was detected at $810 \pm 5^{\circ} \mathrm{C}$ and the composition of the eutectic point was estimated to be $\mathrm{Ni}_{0.48} \mathrm{Ga}_{0.30} \mathrm{As}_{0.22}$. This ternary eutectic point is the lowest temperature at which liquid formation will occur within the 
regions bound by $\mathrm{NiGa}-\mathrm{NiAs}-\mathrm{GaAs}$. This eutectic point could play a significant role in the development of Ni-based GaAs contacts because metallization schemes, including elemental $\mathrm{Ni}$ and compositions within the region bounded by $\mathrm{NiGa}$, NiAs, and GaAs, will experience at least partial melting at temperatures above $810^{\circ} \mathrm{C}$. The formation of a liquid phase is important due to its effect on a contact's morphology and reaction kinetics.

\section{ACKNOWLEDGMENTS}

The experimental data reported in the present article were obtained mostly by C.-H. Jan under DOE Grant No. DE-FG02-86ER45274 and analysis of the data was done under NSF Grant No. DMR-94-24478. The authors would like to thank D. Y. Chen and R. C. Iggulden for their review of the manuscript.

${ }^{1}$ C.-P. Chen, Y. A. Chang, and T. F. Kuech, J. Appl. Phys. 77, 4778 (1995).

${ }^{2}$ N. Braslau, J. Vac. Sci. Technol. A 4, 3085 (1986).

${ }^{3}$ T. C. Shen, G. B. Gao, and H. Morkoç, J. Vac. Sci. Technol. B 10, 2113 (1992).

${ }^{4}$ R. H. Cox and H. Strack, Solid-State Electron. 10, 1213 (1967).

${ }^{5}$ H. G. Fu and T. S. Huang, J. Appl. Phys. 78, 299 (1995).

${ }^{6}$ C.-H. Jan, D. Swenson, and Y. A. Chang, J. Appl. Phys. 68, 6458 (1990).

${ }^{7}$ M. Murakami, W. H. Price, J. H. Greiner, J. D. Feder, and C. C. Parks, J. Appl. Phys. 65, 3546 (1989).

${ }^{8}$ C. C. Han, X. Z. Wang, L. C. Wang, E. D. Marshall, S. S. Lau, S. A. Schwarz, C. J. Palmstrom, J. P. Harbison, L. T. Florez, R. M. Potemski, M. A. Tischler, and T. F. Kuech, J. Appl. Phys. 68, 5714 (1990).

${ }^{9}$ R. Beyers, K. B. Kim, and R. Sinclair, J. Appl. Phys. 61, 2195 (1987).

${ }^{10}$ T. Sands, J. Met. 38, 31 (1986).

${ }^{11}$ C. T. Tsai and R. S. Williams, J. Mater. Res. 1, 820 (1986).

${ }^{12}$ J.-C. Lin, and Y. A. Chang, Mater. Res. Soc. Symp. 148, 3 (1989).

${ }^{13}$ J.-C. Lin, K.-C. Hsieh, K. J. Schulz, and Y. A. Chang, J. Mater. Res. 3, 148 (1988)

${ }^{14}$ F.-Y. Shiau and Y. A. Chang, Mater. Res. Soc. Symp. 148, 29 (1989).
${ }^{15}$ J.-C. Lin, X.-Y. Zhang, K.-C. Hsieh, and Y. A. Chang, Epitaxy of Semiconductor Layered Structures, edited by R. T. Tung, L. R. Dawson, and R. L. Gunshor, Mater. Res. Soc. Symp. Proc. Vol. 102 (MRS, Pittsburgh, 1988), p. 233.

${ }^{16}$ R. Guerin and A. Guivarc'h, J. Appl. Phys. 66, 2122 (1989).

${ }^{17}$ X.-Y. Zheng, J.-C. Lin, D. Swenson, K.-C. Hsieh, and Y. A. Chang, Mater. Sci. Eng. B 5, 63 (1989).

${ }^{18}$ Y. A. Chang, Metall. Mater. Trans. B 25, 789 (1994).

${ }^{19}$ S. K. Kuznetsova, Izv. Akad. Nauk SSSR Neorg. Mater. 11, 950 (1975).

${ }^{20}$ T. Sands, V. G. Keramidas, J. Washburn, and R. Gronsky, Appl. Phys. Lett. 48, 402 (1986)

${ }^{21}$ Phase Diagrams of Binary Nickel Alloys, edited by S. Y. Lee and P. Nash (ASM International, Materials Park, OH, 1990), p. 133.

${ }^{22}$ P. Brand and J. Briest, Z. Anorg. Chem. 337, 209 (1965).

${ }^{23}$ D. Swenson, Ph.D. thesis, University of Wisconsin-Madison, 1994.

${ }^{24}$ T. Sands, V. G. Keramidas, A. J. Yu, K.-M. Yu, R. Gronsky, and J. Washburn, J. Mater. Res. 2, 262 (1987).

${ }^{25}$ A. Lahav, M. Eizenberg, and Y. Komem, J. Appl. Phys. 60, 991 (1986).

${ }^{26}$ C.-H. Jan, D. Swenson, X.-Y. Zheng, J.-C. Lin, and Y. A. Chang, Acta Metall. Mater. 39, 303 (1991).

${ }^{27}$ Binary Alloy Phase Diagrams, edited by T. B. Massalski, 2nd ed. (ASM International, Materials Park, OH, 1990).

${ }^{28}$ M. E. Straumanis and C. D. Kim, J. Electrochem. Soc. 112, 112 (1965).

${ }^{29}$ W. B. Pearson and D. M. Rimek, Can. J. Phys. 35, 1228 (1957).

${ }^{30}$ P. Feschotte and P. Eggimann, J. Less-Common Met. 63, 294 (1979).

${ }^{31}$ S. Bhan and K. Schubert, J. Less-Common Met. 17, 73 (1969).

${ }^{32}$ M. Ellner, S. Bhan, and K. Schubert, J. Less-Common Met. 19, 245 (1969).

${ }^{33}$ E. Hellner, Z. Metlllkd. 41, 480 (1950).

${ }^{34}$ W. Michel, Ann. Phys. (Leipzig) 11, 321 (1963)

${ }^{35}$ R. J. Wasiliwski, S. R. Butler, and J. E. Hanlon, J. Appl. Phys. 39, 4234 (1968).

${ }^{36}$ A. Kjekshus and K. E. Skaug, Acta Chem. Scand. 27, 582 (1973).

${ }^{37}$ R. D. Heyding and L. D. Calvert, Can. J. Chem. 35, 1205 (1957).

${ }^{38}$ G. Aminoff, Z. Kristallogr. 58, 209 (1923).

${ }^{39}$ H. Holseth and A. Kjekshus, Acta. Chem. Scand. 22, 3273 (1968).

${ }^{40}$ M. A. Peacock and C. E. Michener, University of Toronto Studies, Geological Series No. 42, 1939, p. 95.

${ }^{41}$ R. D. Heyding and L. D. Calvert, Can. J. Chem. 38, 313 (1960).

${ }^{42}$ A. Kjekshus and T. Rakke, Acta Chem. Scand. A 31, 517 (1977). 